\title{
SLAVES AND CAPTIVES ON MALTA: 1053/4 and 1091
}

\section{Anthony Luttrell}

espite the desperate scarcity of sources, it is now generally agreed that Detween about 870 and about 1200 Malta was in Muslim hands and that any element of Christian continuity from before 870 can virtually be excluded. Where texts are lacking legend may flourish; but the notion of some Christian survival through the Muslim period, an idea long accepted as ancient unbroken tradition of the type described by Gian Francesco Abela in 1647 as the approuate traditioni hauute da nostri Maggiori, is demonstrably an early-modern invention. ${ }^{1}$ Most of the sources available for the period were indicated and discussed, somewhat disjointedly, in $1975,{ }^{2}$ while others were supplied in Godfrey Wettinger's standard synthesis on Muslim Malta as revised in $1986 .^{3}$ Doubts remain however, especially since Joseph Brincat recently added an important new element to the discussion by noting a passage in the writing of al-Himyari who died in 1494 but used earlier sources. ${ }^{4}$ Further such literary discoveries remain possible but excavation, which might well solve vital problems in this period, is unlikely to be able to

1. A. Luttrell, 'Girolamo Manduca and Gian Francesco Abela: Tradition and Invention in Maltese Historiography', Melita Historica, vii, no. 2 (1977).

2. T. Brown, J. Cassar Pullicino, A. Luttrell et al., in Medieval Malta: Studies on Malta before the Knights, ed. A. Luttrell (London, 1975); note that the Norman invasion should be dated to 1091 and not to 1090 .

3. G. Wettinger, 'The Arabs in Malta', revised edition in Malta: Studies of its Heritage and History, ed. Mid-Med Bank (Malta, 1986); a third addition is forthcoming. V. Grassi, 'Materiali per lo Studio Della Presenza araba nella Regione italiana: i. L'Epigrafia araba nelle Isole maltesi,' Studi Magrebini, xxi (1989). At least one other Arabic inscription on Malta deserves publication. The Maimuna stone, which Grassi, 25, 35 notes as in a class of its own and as coming from Gozo, is first documented in Valletta in 1772 and could have been imported from abroad: A. Luttrell, 'The Roots of Medieval Gozo, Al-Masaq, iv (1991), 52-53; G. Bonello, 'New Light on Majmuna's Tombstone,' Sunday Times (Malta), 735 (8 November 1992), 41. The inscription's stone awaits analysis.

4. J. Brincat, Malta 870-1054: Al-Himyari's Account (Malta, 1991); G. Wettinger's reactions in Sunday Times (Malta), 620 (26 August 1990), 23; 625 (30 September 1990), 16. 
do so for some time. ${ }^{5}$ The Maltese language was scarcely written down until modern times and cannot throw convincing light on the period before 1200 , though toponyms, and especially microtoponyms which clearly persisted for many centuries, ${ }^{6}$ are documented in very considerable number for the fifteenth century and, occasionally, a little earlier. Whether such place names can safely be adduced as evidence for the period before 1091 is extremely doubtful, but since none of them indicates a probable pre-870 toponym they would, if anything, strengthen any theory of a break following the conquest of 870 circa. ${ }^{7}$

There are strong indications, and al-Himyari's text reinforces them, of a Christian opposition to the Muslim attack of 870 which resulted in the dismantling of one or more churches and the death or exile of the bishop and many of the Christian inhabitants on Malta. ${ }^{8}$ Outright resistance on farms or in caves would scarcely have been possible on a small, flat island. It is possible that after 870 there were no Christians, but only Muslims, on Malta; or that a few hundred indigenous Christian inhabitants survived as dhimmi, that is as free citizens of inferior status; or that some inhabitants became mawali or converts to Islam and were accepted as equals; or that they became slaves precisely because they resisted the conquerors of 870 . On a small and distant island the laws of Islam were not necessarily followed strictly and other situations are conceivable. Thus in the tenth century Ibn Hauqal described rural communities in Western Sicily in which Muslim men married Christian women as Islam permitted, their male children being brought up as Muslims and the females as Christians. ${ }^{9}$ In the late-thirteenth century the Sicilian Bartolomeo de Neocastro reported a more fantastic but possibly significant story told by a Muslim on Gerba, according to which the inhabitants of the islands, explicitly including Malta, were the

5. Cf. A. Luttrell, 'Medieval Malta; the Non-Written and the Written Evidence,' in Malta: A Case Study in International Cross-Currents, ed. S. Fiorini and V. MalliaMilanes (Malta, 1991).

6. E.g. M.A. and D. Aquilina et al., in Hal Millieri: a Maltese Casale, its Churches and Paintings, ed. A. Luttrell (Malta, 1976), 26-27 and Fig. 2

7. Wettinger (1986), 90-91.

8. Brown, 81-84; Luttrell (1975), 21-28; Wettinger (1986), 90-91; Brincat, 2, 6-7. Wettinger, 91, says that Maltese Christians must 'undoubtedly' have fled from Sicily to the Italian mainland; but that is a hypothesis.

9. Ibn Hauqal, Configuration de la Terre (Kitab Surat al-Ard), trans. and ed., J. Kramers and G. Wiet, i (Beirut - Paris, 1964), 198; cf. A. Luttrell, 'Ibn Hauqal and TenthCentury Malta', Hyphen (Malta), v, no. 4 (1987),159. 
out to the more numerous slaves that in the event of a Byzantine victory they would be subjected to a captivity and bondage worse than that which would face the free Muslims, who would have friends or allies or a community to redeem them, and the masters promised their slaves that if they joined in resistance to the Byzantines they would, if victorious, be granted their freedom and the daughters of the free minority in marriage. The slaves fought harder than the free Muslims and the majority of the Byzantines were killed, just one ship escaping. ${ }^{15}$ Though some Byzantine prisoners, not necessarily Greeks, conceivably remained on Malta following this defeat, the fact is that no surviving source mentions any other Christians, indigenous or otherwise, on Malta between just after 870 and 1091, and the non-written evidence is similarly silent. ${ }^{16}$

Joseph Brincat seems to accept al-Himyari's account of an island uninhabited for some 180 years and of a deliberate attempt at recolonization. That would imply a complete ethnic break between Byzantine and Muslim Malta, yet he is reluctant to dismiss the implausible notion of Christian communities from before 870 surviving on tiny Malta for a long period in 'hills and valleys ... living or hiding in caves' but leaving no apparent trace of their existence. Despite the strong evidence for Christian opposition in 870 Brincat considers that 'any Maltese survivors from the 870 massacre must have increased, and unless they offered resistance (which would be unlikely) would have been integrated with the new settlers, probably among the slaves.' In that case, however, there would have been no total abandonment. Brincat claims that there are no clues as to the race, creed, or language of the immigrant slaves of $1048 / 9$ but suggests that quite possibly they were neither Arab nor Berber but Christians from Sicily who were of three types: Sicilian Christians, ex-Christians, and Slavs. ${ }^{17}$

15. Text and translation in Brincat, 2-5. Al-Qazwini's less detailed version, which did not mention daughters or marriages, is given in translation by Brown, 84-85. AlQawzini dated the Byzantine attack to 440 (1048/9); Brown, 85, suggests 1038. Wettinger (1986), 91, interpreting Qazwini's slaves as 'a subject population, perhaps indeed partly of indigenous origin, already Islamicized and Arabized ...' implies that al-Qazwini wrote of the Muslims and slaves as 'Maltese'.

16. Wettinger (1986), 91-92; T. Blagg and A. Luttrell, 'Notes on San Pawl Milqi', in T. Blagg, A. Bonanno and A. Luttrell, Excavations at Hal Millieri, Malta (Malta, 1990).

17. Brincat, 7-9. 
offspring of black African men and Byzantine women form Sicily. ${ }^{10}$ Arabic-speaking or Coptic Christians might have reached Malta from the Levant or from Africa; in 827, for example, many Copts were sent from Egypt to Tunisia where they orientalized its Christianity. ${ }^{11}$

It was stated by Ibn Hauqal and a number of other Arabic writers that Malta was totally abandoned in the tenth century. Al-Himyari's account of the conquest strengthens the picture of destruction and abandonment in and after 870, and his claim that Muslims repeopled the island and built a city after 440 , that is after $1048 / 9$, implies a total depopulation of some 180 years and a complete break in ethnic, linguistic, and religious continuities. Al-Himyari repeats the story, known to al-Qazwini in the thirteenth century, of a Byzantine attack on Malta with many ships and a siege of the city, dating it to 445 or $1053 / 4$ and adding new details. ${ }^{12}$ It could have been that a Muslim settlement of 1048/9 circa provoked an almost immediate Byzantine riposte, and it would be unwise to dismiss entirely the idea of a complete abandonment since that would explain the general absence of evidence for continuing occupation; but the balance of probability seems to lie against a complete desertion. The various descriptions of an abandoned island have been explained, quite convincingly, as the result of textual confusion with another place with the similar name of Galita, ${ }^{13}$ and it may be that al-Himyari, faced with evidence both for a total abandonment before $1053 / 4$ and of a community on Malta in that year, sought to resolve the apparent contradiction by inventing a slightly earlier repopulation and the building, or perhaps a rebuilding, of the city. At present only a detailed and exhaustive investigation of al-Himyari's sources and of their manuscript traditions offers even an outside hope of settling that problem. ${ }^{14}$

According to al-Himyari, the 400 free Muslims on Malta and their more numerous abid or slaves were attacked in $1053 / 4$ by the Rum, that is the Byzantines, 'and the Muslims asked them for clemency and they refused it, except for women and belongings.' The free Muslims then pointed

10. Bartholomaeus de Neocastro, Historia Sicula, ed. G. Paladino, in Rerum Italicarum Scriptores, n.s., xiii, part 3 (Bologna,1922), 63-65.

11. A. Luttrell, 'The Christianization of Malta', Malta Year Book 1977 (Malta, 1977), 420.

12. Text and translation in Brincat, $2-5$.

13. Most recently Wettinger (30 September 1990), 16.

14. Brincat, 9.20, discusses such investigations and announces future contributions; Wettinger (26 August 1990), 23, and (30 September 1990), 16, indicates various problems. 
Had the slaves of $1053 / 4$ been descendants of the pre-870 inhabitants they would probably have remained on the island with their women, unless the latter alone had been deported or absorbed by Muslim conquerors, and the men would have had no pressing need to marry the free Muslims' daughters. Had they been Christians, the threat of captivity and bondage under the Christian Byzantines would not have been very compelling. Only if they were Muslims would their condition, already one of slavery, have been likely to be worsened by a Byzantine victory. Furthermore, the free Muslim minority would have been most reluctant, even in an emergency, to trust a more numerous group of Christian slaves with their freedom as equals. That the free Muslims offered their daughters in marriage might suggest that the slaves were not Christian, since Islam prohibits Muslim women from marrying nonMuslims. Godfrey Wettinger points out that had there been Christian survivors from before 870 who remained Christians, they would presumably have been relatively free dhimmi rather than slaves. He suggests a re-peopling of the island, however gradual, by Arabic speakers who might have come from North Africa or other areas to the east or west rather than from Sicily, and he notes that the Muslims are not known to have had Christian slaves on Sicily. Unless in 1053/4 there were dhimmi who were not mentioned by al-Qazwini or by al-Himyari, then there were only free men and slaves; and the latter were unlikely to have been Christian even in origin. ${ }^{18}$ Had the free Muslims' wives and daughters been Christians according to the Sicilian practice reported by Ibn Hauqal, that would have allowed Christian slaves to marry them and might have explained why the Byzantines demanded the women; but that would be to pile hypothesis on hypothesis while leaving other problems unsolved. The reality may have been an untidy and fluctuating jumble of poorly defined personal conditions operating within a very small context.

Brincat writes of a 'total and abrupt change of language' and of the 'lack of a linguistic substratum' in the eleventh century. It could reasonably be supposed that such hypothetical developments would have been the result of some 180 years of total abandonment, if such an abandonment were proven. To assume such developments as facts which support an

18. This is merely to elaborate, in the light of al-Himyari's text, on what has been said by A. Mayr (1896), Brown (1975), 84-85, and Wettinger (1986), 91; idem (26 August 1990), 23; idem (30 September 1990), 16. 
unproven hypothesis of a total abandonment would scarcely be logical. To say that a hypothetical immigration of Sicilians and Slavs in the eleventh century would solve the problem of those Maltese Semitic terms, including knisja for church and qassis for priest, which relate to the Christian religion, is to imply that the existence of the terms in modern Maltese strengthens the hypothesis that the slaves of $1053 / 4$ were Christian and that they reached Malta from Sicily. ${ }^{19}$ In reality there is no such problem, since the Semitic terms are totally undocumented in Maltese until much later and there is no way of demonstrating that they reached Malta as Christian terms in the eleventh century. They could have arrived in a variety of ways and at various times. ${ }^{20}$

The situation on Malta had changed by the time of Count Roger the Norman's attack on the island in 1091. The chief source for that event is the chronicle of Roger's French chaplain and biographer Geoffroi Malaterra, who was either with Roger or received a first-hand account of events. His chronicle included a passage describing how the Muslims' Christian captives, of whom a great number or plurima multitudo were held within the town, came in procession to greet the victorious count:

Videntes autem captivos christianos, ab urve progredientes, prae gaudio suae insperatae liberationis ab imo quoque cordis lacrimis profundi, lingo vel calamis, prout quisque primo inveniebant, compositas cruces in dexteris ferentes, Kyrie eleyson proclamando, ad pedes comitis provolvi, nostri vero ad talem intuitum pietatis affectu lacrimoso rore perfunduntur. Comes ergo, taliter urbe sibi confoederata, captivos, asportet, per naves ordinans, reditum cum magno timore, prae nimio pondere captivorum, ut submersionem veritus, accelerat. Sed dextera Dei, ut credimus, ex eventu patuit: naves per undas sublevans, cubitu uno liberiores super mare ferebat, quam in aditu suo cum eas minus onus gravabat.

This means that by 1091 there were many Christian captives on Malta who went with joy to meet Roger, carrying crosses and crying Kyrie Eleison; Roger took them away, seriously overloading his ships, and devastating Gozo on his way. On reaching Sicily he freed the captives and offered to settle them in Sicily free of any 'servile exaction', but they preferred to return to their own 'fields and

19. Brincat, 7-9; Luttrell, 'Christianity' (1977), 420, provides the literature on these Semitic terms. Brincat has the merit of being the first of the 'philologists' to confront the earlier historical evidence and to seek to place the language in a more acceptable context: cf. J. Brincat, 'Language and Demography in Malta: the Social Foundations of the Symbiosis between Semitic and Romance in Standard Maltese', in Malta: a Case Study ... (1989). The article provides a more convincing account of the origins of the language.

20. Luttrell (1975), 24-25. 
friends' and left for their various homelands, crossing the Straits of Messina. ${ }^{21}$

It might be argued that Malaterra was not present on Malta and was misinformed or inaccurate; certainly he was anxious to exaggerate Count Roger's achievements. ${ }^{22}$ Yet his account of events on Malta appears detailed and circumstantial, so that it seems reasonable to accept the core of his story. Clearly the freed captives were not indigenous to Malta and were not, or mostly not, from Sicily, since they left for their homelands by crossing to mainland Italy. It might seem contradictory that the captives who were full of joy at their release should ask for mercy in Greek. If the captives were Greeks, or mainly Greeks, it might have been that they shouted various remarks and that Malaterra, who presumably knew no Greek but as priest would naturally have recognized the words Kyrie Eleison from the Latin mass and have known that they meant 'Lord have mercy ${ }^{23}$ thought that that was what he heard. Even if this were the case, it would be unlikely that after some forty years the numerous captives of 1091 were survivors from a Byzantine attack of 1053/4. It seems more probable that the 'captives' of 1091 had been taken more recently in battle or by pirates, or have been shipwrecked, or been imported as slaves. If these captives were mainly Latins, and quite possible Italians, they might have carried crosses and shouted 'Lord have mercy' in Greek, perhaps the only Greek words they knew, precisely to emphasize that they were Christians, their joy perhaps being tempered with the fear that the invaders were, as in 1053/4, Greek-speaking Byzantines whom they would have feared as recent and bitter enemies of the Latins.

Brincat claims that the supposedly Christian slaves of $1053 / 4$, the Christian captives of 1091, and the Christians on Malta between 1130 and 1154 were 'markers of continuity'. ${ }^{24}$ In the almost total absence of evidence it is difficult entirely to disprove even apparently unlikely suggestions, yet it is clear that even if the slaves of $1053 / 4$ were Christian they would technically have been bound to have converted to Islam in order to become free men and marry the free Muslims' daughters; that would have broken the continuity. The Christian captives of $1091 \mathrm{did}$

21. Gaufredus Malaterra, De Rebus gestis Rogerii ..., ed. E. Pontieri, in Refum Italicarum Scriptores, n.s. v, part 1 (Bologna, 1927), 94-96: Cassar Pullicino, 100, points out that the story of the Christians carrying palms is a legend.

22. Cf. Pontieri's prefazione; Cassar Pullicino, 97.

23. Cf. P. Siffrin, 'Kyrie Eleison,' Enciclopedia Cattolica, xx (Rome, 1933), 767-768.

24. Brincat, 9. 
not come from Malta and left the island in that year; they could have contributed little or nothing or any Christian continuity. What may be deduced about the Christians of 1127 to 1154 , who are known to have been punished for killing a Muslim on Malta, ${ }^{25}$ is that presumably they reached the island after 1091 when the Christian captives left; most probably they came after the renewed conquest of Malta by Roger I in 1127 and were few in number. ${ }^{26}$ There was, therefore, little room for Christian continuities. The reality was probably confused and untidy with individual exceptions to general developments. If Geoffroi Malaterra was correct in reporting that Count Roger took away from Malta all, or perhaps most, of the Christian captives then on the island, it would follow that Malta was more Muslim after 1091 than before it.

25. Wettinger (1986), 98; Luttrell (1991), 37.

26. Luttrell (1975), 31. S. Fiorini, 'Malta in 1530', in Hospitaller Malta: 1530-1798 Studies on Early Modern Malta and the Order of St John, ed. V. Mallia-Milanes (Malta, forthcoming), notes an Italo-Byzantine familiaris of Roger I who before about 1135 had been exiled to Malta where he spent fifteen years surrounded by Muslims.

ANTHONY LUTTRELL, M.A. (Oxon), D. Phil. (Oxon), F.R. Hist. S., historian and university teacher, Royal Holloway and Bedford New College University of London. 